\title{
Meta-Analysis of Scientific Papers on effects of Motor Skills in the Basketball Published in the Journal Sport Mont from 2006 to 2018
}

\author{
Ivan Vasiljevic ${ }^{1}$ \\ 'University of Montenegro, Faculty for Sport and Physical Education, Niksic, Montenegro
}

\begin{abstract}
The main objective of this research was to be done meta-analysis of original scientific papers published in the journal Sports Mont from 2006 to 2018, who determined the level of motor and situational-motor abilities in basketball players of different ages. In this paper, a meta analysis of 6 papers in the field of motor skills in basketball was conducted. On the basis of the parameters received in said original published scientific papers, it can be concluded that both the base and situational-motor abilities of primary importance for the identification and characterization of young players, and by analogy, and the specialization of basketball game. It is necessary to monitor and apply the achievements of modern sports science, and thus the specific diagnosis of training young athletes. Motor diagnostics in sport is a fundamental science which is the initiator of top results every successful sports team should use at least some sort of diagnostic tools for testing and evaluation of athletes and to create training process.
\end{abstract}

Key words: Meta-Analysis, Sport Mont, Motor Skills, Basketball

\section{Uvod}

Košarka je kompleksna igra zahtjevna u pogledu antropoloških karakteristika i motoričkih sposobnosti. Uspješni igrači se odlikuju polivalentnom tehnikom, izraženom sa morfološkim karakteristikama, funkcionalnim kapacitetima, motoričkim sposobnostima i psiho-socijalnim crtama ličnosti (Šekeljić i Stamatović, 2008). Nezavisno od veličine uzorka, uzrasta i sportskog staža, neophodno je vršiti planirana, organizovana i standardizovana testiranja i mjerenja, kako bi imali uvid u trenutno stanje košarkaša, ali i imali viziju u kojem smjeru treba voditi trenažni proces. Naučnici pokušavaju da otkriju nove metode rada u oblasti sporta, posebno u košarci, u cilju unapređenja procesa treninga i postizanja što večeg nivoa profesionalizacije. Formiranje kvalitetnih košarkaša trebalo bi da se sprovodi sistematski kroz nekoliko osnovnih faza. Svaku etapu više godišnjeg razvoja trebalo bi da karakterišu različi sadržaji, volumena i intenziteta treninga. Pri tome bi neprestano trebalo imati u vidu da je primarni cilj trenažnog procesa u radu sa svim uzrasnim kategorijama stvaranje što kvalitetnijih igrača (Rubin, 2008). Razvoj kvalitetnog košarkaša karakterišu različiti sadržaj, obim opterećenja i intenziteta rada. Vrhunska sportska dostignuća rezultat su čitavog niza činioca, od nasljeđa do sportskog treninga. Uspjeh u igranju košarke kao i drugih sportova, zavisi od većeg broja antropoloških dimenzija (Kocić i Antonijević, 2013). Od poznavanja strukture pojedinih antropoloških sposobnosti i karakteristika, kao i njihovog razvoja, zavisi i kvalitetno upravljanje procesom sportskog treninga (Bjelica, 2005; Bjelica, 2013). Svaki trenažni nadražaj posmatran dugoročno, mora da se upravlja prema biloško-pedagoškim zakonitostima, a na osnovu toga se motoričke sposobnosti mogu razviti postepenim povećanjem opterećenja uz primjenu određenih metoda (Bjelica i Fratrić, 2011). Mišićna masa poboljšava sportsko postignuće u aktivnostima koje zahtevaju mišićnu snagu i izdržljivost ali i u onima koje zahtijevaju zavidnu aerobnu sposobnost (Ćorluka \& Vasiljević, 2018). Pripadnost sportiste jednoj sportskoj grani

Correspondence:

Montenegrro I. Vasiljevic

Gport University of Montenegro, Faculty for Sport and Physical Education, Narodne omladine bb, Niksic, Montenegro e-mail: vasiljevic.ivan301@gmail.com 
podrazumijeva njegov biotip, koji mu daje prednost da se bavi baš tim sportom u odnosu na druge (Ćorluka \& Vasiljević, 2018). Snažna ekspanzija košarkaške igre praćena je širom svijeta, a kod nas je takođe stvorila uslove da se podstakne razvoj i unapređenje naučno metodskih osnova trenažnog procesa kao i ostalih faktora koji će uticati da se dođe do vrhunskih sportskih rezultata. Osnovni cilj ovog istraživanja je bio da se uradi meta analiza originalnih naučnih radova objavljenih u časopisu Sport Mont od 2006 do 2018, koji su utvrđivali nivo motoričkih i situaciono-motoričkih sposobnosti kod košarkaša različitog uzrasta.

\section{Metode}

Analiza sadržaja je metoda često prisutna u istraživanjima koja kvalitativno i kvantitativno sistematizuje objavljene radove na određenu temu, a u jednostavnijem obliku se koriste zbrajanje i deskripcija pomenutih radova. Jedinica analize sadržaja u ovom preglednom radu su naslovi originalnih naučnih istraživanja objavljenih u časopisu „Sport Mont“ od 2006. do 2018. godine. Izdvojeno je šest objavljenih radova u ovom periodu. Radovi su klasifikovani po jednostavnom kriterijumu, a to je da se bave efektima motoričkih sposobnosti kod košarkaša različitog uzrasta. Od statističkih procedura u navedenim radovima korišćene su multivarijntna analiza kovarijanse, pirsonova korelaciona analiza i faktorska analiza.

\section{Rezultati}

Iz pregleda svih ovih objavljenih originalnih naučnih radova koji se analiziraju, jasno je da je riječ o transverzalnim i longitudinalnim istraživanjima sa ciljem da se utvrdi nivo motoričkih sposobnosti košarkaša različitog uzrsta. Riječ je o sljedećim radovima:

"Struktura motoričkih sposobnosti košarkaša". Kocić i Antonijević, (2013) su sproveli istraživanje sa ciljem da se utvrdi struktura motoričkih sposobnosti. Na uzorku od 132 košarkaša, košarkaškog kluba „Student“ iz Niša upotrijebljeno je 13 motoričkih testova i utvrđeno je da visoki igrači dužih ruku i nogu imaju određenu prednost pred nižim igračima, odnosno sa igračima sa kraćim ekstremitetima.

"Efekti treninga na merene specifično-motoričke sposobnosti košarkaša i košarkašica kadetskog uzrasta”. Rubin (2008) je realizovao istraživanje sa ciljem da se utvrdi da li postoje značajne razlike u efektima programiranog desetodnevnog trenažnog rada, između košarkaša i košarkašica kadetskog uzrasta, na osnovu (testovima) izmjerenih specifično-motoričkih sposobnosti. Uzorak je činilo ukupno 20 ispitanika uzrasta 15 godina ( \pm 6 meseci), a od situacionih testova su korišćeni kretanja igrača sa loptom, manipulisanja loptom, kretanja igrača bez lopte i poligon. Značajna statistička razlika (na nivou $\mathrm{p}=.00$ ) $\mathrm{u}$ efektima trenažnog rada dobijena je kod tri varijable (testa): Vođenje lopte oko centralnog kruga; Kruženje loptom oko tijela i Kamikazi.

"Povezanost eksplozivne snage donjih ekstremiteta sa rezultatima testova za procjenu agilnosti kod mladih košarkaša”. Fratrić (2006) je sproveo istraživanje sa ciljem da se utvrdi povezanost eksplozivne snage na rezultat u testovima za procjenu agilnosti. Na uzorku od 85 košarkaša primijenjena je baterija testova za procjenu eksplozivne snage donjih ektremiteta i agilnosti. Faktorskom analizom tri varijable dobijena je latentna dimenzija definisana kao eksplozivna snaga donjih ektremiteta. Rezultati istraživanja su pokazali da je eksplozivna snaga donjih ektremiteta statistički značajno povezana sa oba testa za procjenu agilnosti. Takođe, razlike $\mathrm{u}$ stepenu povezanosti između dva testa za procjenu agilnosti ukazuju da je test za procjenu košarkaške agilnosti više uslovljen eksplozivnom snagom i da je međuodnos brzine snage i drugih motoričkih sposobnosti koji utiču na rezultat u testovima agilnosti pomjeren $\mathrm{u}$ korist eksplozivne snage.

"Relacije motoričkih i situaciono-motoričkih sposobnosti u košarkaškoj igri”. Mirvić (2006) je utvrđivao relacije motoričkih sposobnosti i situaciono-motoričkih sposobnosti u košarkaškoj igri. Na uzorku od 120 ispitanika uključeno je 8 varijabli za procjenu bazično-motoričkih sposobnosti i 3 testa za procjenu situaciono-motoričkih sposobnosti košarkaške igre. $\mathrm{Na}$ osnovu dobijenih rezultata u okviru ovog istraživanja može se utvrditi da bazično-motoričke sposobnosti imaju statistički značajnog i pozitivnog uticaja na rezultatsku uspiješnost u košarci. Analizom rezultata dobijenih regresionom analizom u latentnom prostoru, odnosno uticaja pojedinačnih bazično-motoričkih varijabli na jednodimenzionalnu kriterijumsku varijablu može se zaključiti da najveći i statistički značajan uticaj imaju: stisak šake, brzina trčanja i agilnost i eksplozivna snaga nogu.

"Uticaj trenažnog procesa na razvoj eksplozivne snage nogu kod košarkaša pionirskog uzrasta” (Badža i Sudar 2011). Planirano istraživanje je sprovedeno na košarkašima košarkaškog kluba „Danubius Vojvodina Srbijagas” iz Novog Sada na uzorku od 20 košarkaša. U ovom istraživanju za projcenu eksplozivne snage nogu bila je primijenjena sljedeća baterija testova: skok udalj iz mesta, skok u vis iz mesta i trčanje $20 \mathrm{~m}$. U ovom istraživačkom radu utvrđeno je da je došlo do statistički značajnog povećanja eksplozivne snage nogu i može se smatrati da su dobijeni rezultati posljedica adaptacije na uticaj trenažnog procesa. Daljom statističkom analizom došlo se do rezultata koji ukazuju da je stistički značajna razlika dobijena između sva tri mjerenja tj. Između inicijalnog i kontrolnog mjerenja, inicijalnog i finalnog kao i između kontrolnog i finalnog mjerenja. Dobijeni rezultati takođe pokazuju da je došlo do značajnog poboljšanja u svim varijablama za procjenu eksplozivne snage nogu.

"Antropometrijske karakteristike i motoričke sposobnosti mladih košarkaša Crne Gore" (Ljubojević i Nikolić 2012). Cilj ovog rada bio je da prikažu osnovne karakteristike i sposobnosti mladih košarkaša Crne Gore i njihovo poređenje sa drugim reprezentacijama. Uzorak su sačinjavali selektirani mladi košarkaši uzrasta 17-18 godina, koji su prošli cjelokupne pripreme juniorske reprezentacije Crne Gore za Evropsko prvensto B divizije 2011. godine. Iz motoričkog prostora praćene su slijedeće varijable: zadnji čučanj, potisak sa ravne klupe, zadnji potisak, ležanje- sjed za $30 \mathrm{~s}$, Sardžent test, skok udalj, test 20 jardi, kamikaze, špagat i sjedeći pretklon. Poslije sprovedenog mjerenja i testiranja i analize rezultata dobijenih na testovima iz motoričkog prostora, može se zaključiti da crnogorski mladi košarkaši imaju slabije rezultate vertikalnog skoka Sardžent testa od vršnjaka iz Srbije, u testu skok u dalj, imaju slabiju eksplozivnu snagu nogu od vršnjka iz Srbije, ali i bolje rezultate na testovima špagat test i sjedeći pretklon, što pokazuje da posjeduju veću fleksibilnost.

\section{Diskusija}

U ovom radu su izdvojena originalna istraživanja objavljena u časopisu "Sport Mont od 2006. do 2018. U časopis “Sport Mont” se objavljuju originalni recenzirani naučni članci i interdisciplinarni prikazi istraživanja iz oblasti sportske nauke. Svrha časopisa je promocija nauke i istraživanja, sa posebnom 
pažnjom posvećenom sportskoj nauci širom Crne Gore i izvan nje. Meta-analiza daje pregled objavljenih originalnih naučnih radova iz oblasti motoričkih sposobnosti odbojkaša/ica u časopisu "Sport Mont" od 2006 do 2018. godine. Utvrđeno je da su objavljeni radovi imali za teme jednu od najsavremenijih tendencija u sportskim naukama, dijagnostikovanje bazičnih i situacionih motoričkih sposobnosti mladih košarkaša. Ta istraživanja mogu biti korisna i za dalja teorijska istraživanja, kao i za praktičnu primjenu u navedenom sportu. $\mathrm{Na}$ osnovu uvida u dobijene parametre $u$ navedenim objavljenim originalnim naučnim radovima, može se zaključiti da su i bazične i situacione-motoričke sposobnosti veoma bitne za identifikaciju i karakterizaciju mladih košarkaša, a analogno tome i specijalizaciji košarkaške igre. Potrebno je pratiti i primjenjivati dostignuća savremene sportske nauke, a time i specifičnu dijagnostiku treniranosti mladih sportista. Takođe dobijeni podaci se mogu usmjeriti u pravcu inoviranja planova i programa trenažnog procesa i prilagođavanju istih potrebama navedene populacije. Motorička dijagnostika u sportu je fundamentalna nauka koja je pokretač vrhunskih rezultata, i svaki uspješni sportski kolektiv trebalo bi da koriste bar neku vrstu dijagnostičkih alata za testiranje i evaluaciju sportista i za kreiranje trenažnog procesa.

\section{Acknowledgements}

There are no acknowledgements.

\section{Conflict of Interest}

The authors declare that there are no conflicts of interest.
Received: 25 August 2018 | Accepted: 19 September 2018 | Published: 29 October 2018

\section{References}

Badža, V., i Sudar, D. (2011). Uticaj trenažnog procesa na razvoj eksplozivne snage nogu kod košarkaša pionirskog uzrasta. Sport Mont, 8(25-26-27), 230-4

Bjelica, D. (2005). Sistematizacija sportskih disciplina $i$ sportski trening. Podgorica: Crnogorska sportska akademija.

Bjelica, D. (2013). Teorija sportskog treninga. Podgorica: Univerzitet Crne Gore.

Bjelica, D., i Fratrić, F. (2011). Sportski trening: teorija, metodika i dijagnostika. Nikšić: Fakultet za sport i fizičko vaspitanje.

Ćorluka, M., \& Vasiljević, I. (2018). Differences in the morphological characteristics and body

composition of football players in montenegro. Journal of Physical Education and Sport, 1(1), 3-7.

Fratrić, F. (2006). Povezanost eksplozivne snage donjih ekstremiteta sa rezuItatima testova za procjenu agilnosti kod mladih košarkaša. Sport Mont, 4(10-11), 203-8.

Kocić, J., i Antonijević, S. (2013). Struktura motoričkih sposobnosti košarkaša. Sport Mont, 11(37-38-39), 364-9.

Ljubojević, M. i Nikolić, B. (2012). Antropometrijske karakteristike i motoričke sposobnosti mladih košarkaša Crne Gore. Sport Mont, 10(34-3536), 174-80.

Mirvić, E. (2006). Relacije motoričkih i situaciono-motoričkih sposobnosti u košarkaškoj igri Sport Mont, 4(10-11), 74-9.

Rubin, P. (2008). Efekti programiranog trenažnog tretmana na merene specifično-motoričke sposobnosti košarkašica kadetskog uzrasta. Sport Mont, 6(15-16-17), 72-7.

Šekeljić, G., i Stamatović, M. (2008). Hipotetski petodimenzionalni prostor bazičnih faktora ekstrahovan faktorskom analizom iz skupa morfoloških karakteristika, motoričkih sposobnosti i manefestnih košarkaških varijabli. Sport Mont, 6(15-16-17), 690-7. 